


\section{Jurisdictional Justice, Democracy and the Story of Insite}

\section{Hester Lessard*}

Insite, North America's first legally sanctioned safe injection site, opened its doors in 2003. It did so after several years of political struggle by a network of community groups in Vancouver's Downtown Eastside (DTES), the neighbourhood it serves. The grassroots movement secured support at municipal, provincial, and federal levels of government. The latter expressed its approval by granting an exemption that protected Insite staff and patients from prosecution for possession of illegal substances under the federal Controlled Drugs and Substances Act (CDSA). ${ }^{1}$ The remarkable political consensus in favour of Insite came apart in 2008 when the federal government, after the election of the Harper Conservatives, declined to extend the exemption. As a consequence, Vancouver Area Network of Drug Users (VANDU) and the Portland Hotel Community Services Society (PHS), the non-profit that operates Insite, along with two Insite clients, brought an action against the federal government in the B.C. Supreme Court. The provincial government intervened. ${ }^{2}$ The key arguments were that either the CDSA is inapplicable (and therefore the exemption is unnecessary) because primary jurisdiction over health resides with the province, or that the application of the provisions prohibiting possession in the federal statute violates the section 7 Charter rights ${ }^{3}$ of clients seeking treatment at Insite.

In PHS Community Services Society $v$ Canada (Attorney General), PHS Community Services Society was successful at trial ${ }^{4}$ and at appeal. ${ }^{5}$ The case will be heard by the Supreme Court of Canada on May 12, 2011. ${ }^{6}$ Both Pitfield J at the trial level and Rowles JA at the Court of Appeal relied on the Charter to find in Insite's favour. They determined that the application to Insite clients of CDSA provisions prohibiting possession of illegal drugs would violate the section 7 Charter rights in a manner that cannot be justified in a free and democratic society. Rowles JA also agreed with her colleague Huddart JA's analysis, which found in Insite's favour on the basis of the division of powers. As Huddart JA declined to explore the Charter arguments, her reasons represent the majority position at the Court of Appeal. Huddart JA held that the subject matter of Insite lies at the core of the exclusive jurisdiction of the provincial government over hospitals and health and is thus immune, under the doctrine of interjurisdictional immunity, from impairment by the operation of the CDSA.

There was one dissent-by Smith JA-at the Court of Appeal. She rejected the interjurisdictional immunity argument (as indeed did Pitfield $J$ at the trial level) by referring to recent decisions of the Supreme Court of Canada that have urged a restricted application of the doctrine. She also rejected the Charter argument. Here, she found that although section 7 interests in life, liberty and security of the person are threatened by the application of federal narcotics prohibitions to clients seeking treatment at Insite, those prohibitions are nevertheless consistent with the principles of fundamental justice.

The considerable judicial support for Insite-three out of the four judges that have presided so far-is significant. Despite the disagreement over which constitutional path to take, the 
support speaks to the compelling nature of the justice claim underlying the doctrinal arguments. However, choice of constitutional paththe Charter or the division of powers-is also significant as, at least theoretically, it should explain why we, as constitutional citizens, should care deeply about the dispute over Insite. The Charter and its underlying constitutional values would seem to speak directly to the dignity harms and survival interests of the individuals who depend on Insite for treatment. Furthermore, when compared to Charter jurisprudence, much division of powers jurisprudence is arid and technical. There is, perhaps, no better example of this than the doctrine that provides the foundation for the Court of Appeal's majority decision, namely, the interjurisdictional immunity doctrine. Nonetheless, I think there is an issue of jurisdictional justice that eludes the language of rights emanating from the Charter and that fits more comfortably within the division of powers framework.

Jurisdictional issues in federalism disputes deal with the question of where political authority to address a particular issue resides. In this case, the jurisdictional dispute revolves around issues of addiction and its treatment in Vancouver's Downtown Eastside (DTES), and by implication, elsewhere in the province. I want to suggest that the political mobilization at the grassroots level that led to the establishment of Insite should be a contextual factor in deciding the jurisdictional question and hence in deciding whether the interjurisdictional immunity doctrine protects the province's exclusive jurisdiction over health care. My conceptual point is straightforward. Jurisdictional disputes between the provinces and the federal government are commonly understood to be shaped by the principle of federalism-the commitment to reconcile unity with diversityas well as by principles of democracy. The jurisprudence understands diversity and democracy in very formal terms, namely in terms of levels of government within a federal system, and the configuration of the population into provincial and national majorities, each with its set of representative institutions. I argue that this formal calculus of diversity and democracy should be textured by a more substantive account of polit- ical engagement at the community level where two crucial elements are present. The first element is the voicelessness or political marginality of the community in question in relation to conventional institutional channels of democratic change. The second element is the fundamental nature of the interest at stake for that community. Both elements are present in the story of the struggle of the user community to establish Insite.

My argument that federalism jurisprudence should incorporate a fuller, more substantive consideration of democratic principles parallels one that is now commonly made in relation to rights jurisprudence and to the amending process, namely, that social movements are and should be key actors in shaping the substantive content of constitutional norms and principles. ${ }^{7}$ I would, however, go further and argue that where the core principles animating the constitutional text are rooted in concerns about democracy, there are strong reasons for judges to take explicit account of such political engagement.

I will start by laying out key aspects of the story of the harm reduction movement that formed in the DTES in response to a health crisis caused by addiction. Drawing on a rich secondary literature, including ethnographic, geographic and drug policy studies, I will focus only on the early efforts of the community and its initial political mobilization (roughly from 1988 to 2000) in the face of very little support from the political establishment and seeming public indifference to the rising death toll from addiction-related causes. The subsequent steps in gaining political support for Insite also involve democratic processes both in and outside of government. However, this later chapter in the story is not as germane to my main conceptual point. The principles of federalism, diversity, and democracy at stake in the governmental and intergovernmental deliberations have at least formal representation in the judicial analysis of Insite's constitutional positioning in relation to the division of powers. In contrast, the conventional judicial calculus provides little, if any, space for examining the mobilization of a profoundly marginalized community around 
issues of survival in the face of overwhelming silence in the larger political sphere. In the second part of this essay, I provide a brief overview of the discussion of the interjurisdictional immunity doctrine in recent Supreme Court of Canada cases, focusing on aspects that relate to the doctrine's use in Huddart JA's reasons. In the third section, I discuss how the jurisprudential narrative about jurisdiction might engage more fully with the community narrative about self-government.

\section{Part I: The story of Insite: The community narrative about self-government}

The DTES comprises an area that is roughly three kilometres along the east-west axis and two kilometres along the north-south axis. It lies along the Burrard inlet just east of the downtown commercial centre of contemporary Vancouver and is one of the most densely populated and diverse neighbourhoods in the city. Traces of its original Coast Salish inhabitants, who had fishing camps, villages, and trails in the area, have long ago been overlain by the rapid urbanization that took place in the late nineteenth century. Nevertheless, "cultural memories of dispossession" 8 live on, sustained by the significant concentration of indigenous peoples drawn from local and distant communities who currently reside there. Colonialism is both past and present in the DTES, prompting some to demand recognition of the neighbourhood and similar urban spaces in Canada as neo-colonial spaces that remain "unsettled." Nicholas Blomley, in particular, observes that the Coast Salish have been dispossessed but not displaced, that "the settler-city not only was, but still is, native land."10 The argument is particularly powerful in the DTES, in which estimates suggest that between $10 \%$ and $40 \%$ of the roughly 16,500 inhabitants are indigenous peoples. ${ }^{11}$ The indigenous presence shapes the character of the community, not simply through formal visible markers such as the totem, "Standing with Courage, Strength and Pride," carved and raised in Oppenheimer Park in 1998, but in more subliminal ways. Adrienne Burk, who has chronicled social mobilization in the neigh- bourhood, notes "the keen cultural awareness of the high visibility of First Nations people in the Downtown Eastside; in virtually every meeting I have attended in the neighbourhood (and, in any government meetings), there have been verbal, behavioural, or cultural references to First Nations traditions." 12 This palpable and numerically strong presence, however, has not translated into political voice. Activists express frustration at the fact that while indigenous people in the DTES are often recognized as an important client group for services, they are seldom viewed as political agents. ${ }^{13}$

The DTES is a truly heterogeneous and demographically distinctive neighbourhood. Roughly $45 \%$ of the population is comprised of first-generation immigrants to Canada. ${ }^{14}$ In some parts of the neighbourhood, men far outnumber women, giving the neighbourhood an overall $62 / 38$ male to female population split. ${ }^{15}$ It has twice the seniors (22\%) and half the children and youth (2\% and $8 \%)$ than the rest of the city. ${ }^{16}$ It also has roughly three times the number of persons living alone than the rest of the city. The DTES is notorious as the poorest postal code in Canada. Census figures (which do not include homeless persons or persons whose income is not reported) put the median income at $\$ 12,084$, and the unemployment rate $(22 \%)$ is almost three times the rate in the rest of the city. ${ }^{17}$ Close to $40 \%$ of DTES residents rely on transfer payments for support and $67 \%$ of households are in the low-income categorycompared with $27 \%$ in the city as a whole. ${ }^{18}$

The nature of the neighbourhood is such that violence, both public and private, is a part of daily life and, as elsewhere, such violence deeply marks the lives of women, especially racialized and indigenous women. Since 1983, approximately 69 women associated with the neighbourhood-many of them indigenous, sex trade workers, and injection drug users-have disappeared. Leslie Robertson and Dara Culhane, echoing observations about the political voicelessness of indigenous residents more generally, note that women in the DTES are simultaneously visible and invisible. ${ }^{19}$ For years, efforts by friends and family of the missing women to gain the attention of the police and 
public were ignored. Slowly, other forces joined in pressuring authorities, and eventually investigations were undertaken. Local, national and international media attention exploded as evidence began to point in the direction of a serial murderer. The process culminated in the arrest of Robert Pickton in 2002 and his conviction in 2007 on six counts of second-degree murder. However, despite the sensational nature of the coverage of the Pickton trial, the feeling of invisibility remains palpable. As one resident, a Cree woman and injection drug user, put it: "See, the buses come and go down here, and you see people looking. But they don't see nothing. All they see is the dope. People can hide in plain sight. They can be this far from you. . . . [T]he thing is these people, they're invisible to society." 20

A number of converging factors compound the social and political invisibility of DTES residents. The commonplace "conflation of persons and place occurring in stigmatized space" ${ }^{21}$ is, in the case of the DTES, exacerbated by the criminalization of its residents as addicts, drug dealers and sex trade workers, and by their subsequent medicalization as public officials began to seek responses other than law enforcement to the steeply climbing rates of overdose deaths and HIV infection. Moreover, detractors frequently characterize the DTES population as transient, despite the fact that it is a remarkably stable community. ${ }^{22}$ In a property discourse dominated by what Blomley calls private property's "ownership model," the homeless person or long-term hotel dweller loses any place-based entitlement to belong. Her claim to be and remain in the neighbourhood is rendered incoherent. ${ }^{23}$ Gentrification in the DTES increasingly threatens to displace many such residents, eclipsing their "community land claim." ${ }^{24}$ The claim is based on their collective investment in the physical space through use, habitation, action, and struggle-an investment that has produced a landscape with powerful material and representational dimensions. ${ }^{25}$ For example, Oppenheimer Park, the site of the "Standing with Courage" totem and of VANDU's first meeting, is often referred to by DTES residents "by terms generally used for a dwelling (our 'back yard, our living room')." 26
Accounts of the escalation of addiction problems in the DTES during the 1980s are surreal. In the 1970s, the city opened a facility to house "the sixty seven people police had identified as the most problematic in the neighbourhood." ${ }^{27}$ By the end of the 1980s, this relatively manageable situation had transformed; the DTES "was home to one of the fastest growing open-air drug markets in Canada, an infrastructure of illegitimate businesses to support this market, and the epicentre of an epidemic of property crime." ${ }^{28}$ More significantly, "people were dying in great numbers." ${ }^{29}$ The neighbourhood, in particular the user community, began to respond on an $a d$ hoc and then more concerted basis, and a harm reduction movement started to mobilize. The movement integrated health concerns-reduction of overdose deaths and the transmission of infectious diseases-with social concerns such as access to toilets, physical safety, and police harassment. At the time, the entrenched understanding of addiction to illegal narcotics was the criminal model. Canada endorsed a harm reduction approach in 1987 that, on paper at least, acknowledged the ineffectiveness of the criminal model, emphasizing instead the health dimension of addiction. However, enforcement activities continued to escalate and the bulk of funds earmarked for harm reduction went to police drug education programs that adhered to a traditional message. ${ }^{30}$ Meanwhile, health care policy remained by and large committed to an abstinence-based treatment model that often relied on punitive measures to achieve compliance. In contrast, a harm reduction approach requires a fairly profound shift in thinking. It challenges not only the view that addiction is deviant behaviour best addressed through the criminal law, but also the view that addiction is exclusively a disease. Harm reduction approaches, when implemented as part of a governmental drug policy regime, typically are combined with enforcement measures aimed at trafficking and abstinence strategies. However, the approach is premised on the recognition that social factors such as homelessness, poverty, gender inequality, colonialism and racism must be factored into the understanding of addiction. Thus, a more comprehensive and flexible set of supports and resources are required for "treatment," the aim of which is primarily to 
reduce disease and death and achieve stability rather than to reduce addiction. ${ }^{31}$

The DTES activist and user community began to pursue a number of harm reduction, selfhelp strategies at the end of the 1980s. In 1988, social activist John Turvey was so concerned about the rise in infectious diseases related to injection drug use, that he "started singlehandedly giving out three thousand clean syringes a month." ${ }^{32}$ Eventually, his organization received a government grant and opened the first official needle exchange in Canada in 1989. ${ }^{33}$ In 1991, a weekly support group called Drug and Alcohol Support Group for Women (DAMS) was set up by volunteer health professionals and social workers who were unable to obtain funding because they pursued a harm reduction rather than abstinence approach. ${ }^{34}$ The women in the group were primarily mothers, and indigenous. Importantly, the harm reduction approach permitted "recognition of the social factors that shape women's lives and acknowledgement that women's drug use differs from men's," 35 as well as being differentiated in relation to class, ethnicity, race, sexuality and culture. Thus, for example, "reunification of the family was a central component of the program because most of the women who participated in DAMS had at least one child apprehended by the state." 36

Meanwhile, however, the rate of overdose deaths in B.C. continued to climb, going from 39 in 1988, to 331 in 1995, and to 417 in 1998, the worst year on record. ${ }^{37}$ Also, the spread, via unsafe injection practices, of infectious diseases-HIV/AIDS, Hepatitis A, B, and C, and other skin and blood-borne infections-as well as the development of a constellation of associated conditions-septicaemia, endocarditis, aggravated mental illness, foetal exposure to narcotics-began to reach epidemic proportions. ${ }^{38}$ The situation was highly visible at the community level of health care provision and was not unnoticed at governmental levels. However, no comprehensive response was undertaken, leaving the neighbourhood to continue to pursue its own strategies. ${ }^{39}$ A lobby group of drug users called IV Feed was formed, and in the Fall of 1995 it set up Back Alley, an illegal injection site that operated for a year, with informal sup- port from the B.C. Centre for Disease Control (free syringes, and occasional visits by a nurse) and with no serious interference from police. It closed because of lack of funds. ${ }^{40}$ Another group, called the Political Response Group, staged eighty demonstrations demanding better services for addicts. The most prominent was the "thousand crosses demonstration" in 1997. Traffic on a main artery running through the neighbourhood was blocked, leaflets were handed out detailing the epidemic of overdose deaths, and while indigenous elders drummed and sang, a thousand crosses were planted in Oppenheimer Park, presenting a powerful image in public space of the toll taken by drugrelated deaths. ${ }^{41}$

The organization of the two institutional applicants in the Insite litigation-VANDU and PHS-occurred in 1998 and 1993 respectively. Starting in 1997, a number of advocacy and support groups in the neighbourhood-IV Feed, Political Response Group, MindBody Love, the Compassion Club, the Hype, and HCV+IDUbegan discussing the development of a drug user organization as a means of coping with the epidemic of addiction-related deaths and health issues. ${ }^{42}$ The result was VANDU. It commenced with a meeting in Oppenheimer Park in September 1997 organized by Ann Livingston, a non-user and harm reduction activist who had been instrumental in setting up Back Alley, and Bud Osborn, a DTES resident and former heroin addict, social activist, poet, and member of the Vancouver-Richmond Health Board. Osborn and Livingston plastered the neighbourhood with flyers inviting people to take a "community approach" to a list of five issues, none of them specifically about addiction, but all of them imbricated in the experience of addiction in the DTES. The five issues were: "police conduct, 'is this your home?', neighbour relations, violence and safety, washroom facilities." ${ }^{\prime 3}$ This inaugural meeting was followed by several more at a church and then by weekly user meetings, out of which VANDU arose. Osborn convinced the Health Board to declare a public health emergency in 1997 and to provide VANDU with the small grant that launched its formation in January $1998 .{ }^{44}$ VANDU founders identified political marginalization and "the distance that us- 
ers are from society" as a key obstacle. ${ }^{45}$ As the membership grew in size (from 20 to 100 in the first few months, and eventually to more than $2,000),{ }^{46}$ the original founders involved participants in facilitating subsequent meetings, planning agendas and publicity, and developing action plans arising out of group discussions. With its membership consisting of "economically impoverished, ill and courageous drug addicts," VANDU took as its first objective "to change the demonizing rhetoric they endured using community meetings, demonstrations, education and fearlessness in the face of repression." ${ }^{37}$ In short, VANDU set out to demand a part for injection drug users in the broader political conversation about addiction and the neighbourhood, a conversation in which, to that point, their members had only featured as the face of "the problem."

In its effort to demand that injection drug users occupy political space as agents rather than objects, VANDU reached outward to challenge discourse in the broader public sphere that condemned the neighbourhood as deviant and beyond repair. For example, demonstrations were organized to contest Constable Mark Tonner of the Vancouver Police Department's portrayal of DTES injection drug users as "vampires" and "werewolves" in a weekly column he wrote for a city newspaper. ${ }^{48}$ And when home and business owners associations pursued an agenda against harm reduction, asking instead for more law enforcement, harm reduction activists responded with more demonstrations and circulated a poster that asked "Why don't you just kill us?"49 Yet, not all of VANDU's interventions involved direct action of this sort. The notes from the user meetings record discussions about sharing public spaces with children and elderly, police harassment and racial profiling of Latino/a residents as drug dealers, police violence against indigenous residents, the harm reduction approaches pursued in Europe, as well as about larger systemic issues-the role of poverty, the effects of criminalization, and the absence of any political voice or credibility for injection drug users in the face of "war on drugs" rhetoric. As one participant asked: "Why should people be homeless, sick, beat up, etc., because they use drugs?"50 Or as a protest sign stated: "Drug
Users are People Too! They deserve compassion and a place in the Community!"51

A recurrent theme in the VANDU minutes is the need for a harm reduction rather than a crime control approach, and, as a central feature of harm reduction, a safe injection site that is legal, user-controlled, and adequately funded to provide health and social support services. ${ }^{52}$ VANDU's programmatic achievements over the years have included creating peer support and mentorship relationships; obtaining CPR training for addicts; inviting guest speakers; creating support groups for people on methadone, women with HIV, and those with Hepatitis C; patrolling back alleys to reach high risk drug users; creating used syringe recovery and syringe exchange programs; lobbying for, and then supervising, night-time public toilets, creating drop-in centres; visiting hospitalized drug users; and engaging in educational activities including participating in local, national and international conferences. ${ }^{53}$

VANDU takes the anti-slavery, civil rights, and women's movements as its models. Its commitment to challenge "traditional client/provider relationships and empower people who use drugs to design and implement harm reduction interventions," is reflected in its governing structure. Anyone can join VANDU, but only addicts or former addicts have a vote at meetings or can be elected to its governing board. Supporting members have a voice but no vote at meetings and cannot exceed $10 \%$ of the entire membership. ${ }^{54}$ The demographic make-up of the membership is roughly estimated to be $1 / 3$ women and $1 / 3$ indigenous peoples, with members ranging in age from 10 to 70 but clustered around the ages 30 to $50 .{ }^{55}$

PHS, the other institutional plaintiff in the Insite litigation, was formed by the Downtown Eastside Residents Association. It is named after the Portland Hotel, a residence it administers "for adults with mental illnesses, addictions and other problems" with funds from the Vancouver Coastal Health Authority and the B.C. Housing and Mortgage Corporation. ${ }^{56}$ It is both an advocacy group and a service provider for its residents and the neighbourhood. ${ }^{57}$ As such, its staff saw first-hand the impact of rising 
addiction rates in the 1990s. PHS sponsored a conference in 1998 in Oppenheimer Park that drew together politicians, government bureaucrats, harm reduction experts from the U.K. and Europe, and neighbourhood drug users. ${ }^{58}$ Although government acceptance of a harm reduction approach was still several years away, PHS often was able to bridge the divide between the neighbourhood and governmental bodies while still remaining "of the neighbourhood."

As the harm reduction movement gained force in the DTES, it also started to acquire powerful allies, among them Larry Campbell, B.C.'s Chief Coroner at the time, who was dealing first-hand with the increasing amount of deaths; Ken Higgins, a former Vancouver deputy police chief; Dr. John Millar, the provincial health officer; and the Health Officer's Council of B.C. ${ }^{99}$ Phillip Owen, Vancouver's mayor during the crucial years of 1993 to 2002, was initially unequivocally against harm reduction strategies. However, he eventually became a strong and articulate promoter of a "fourpillars" approach, which included harm reduction as one of its pillars. Libby Davies, the New Democratic Party MP for Vancouver East also became an outspoken supporter of harm reduction. In short, despite being ill, often homeless, and impoverished, harm reduction activists and injection drug users in the DTES managed to push back against their profound political invisibility. They crafted their own institutions and supports, and engaged in direct action and protests. In a remarkable and sustained demonstration of political agency, they challenged their construction as victims or deviant outsiders. Eventually, they succeeded in actively engaging powerful actors in the public sphere, "talking back" to negative press, and forming coalitions and alliances that crossed class, neighbourhood and international lines.

It is at this point in the story, in late 1998 and 1999, that action at the community level expanded and the project began to move through municipal, provincial and federal channels. After the release of a Health Board Report calling for four safe injection sites, Davies and Osborn met with federal health officials to discuss a strategy to obtain an exemption under the
CDSA and to secure governmental support for Insite. While serious resistance still remained at the federal, provincial and municipal government levels, a much broader-based public discussion in Vancouver and the province began to unfold over the next five years, with active participation by neighbourhood activists and drug user groups such as VANDU. This eventually led to the consensus at the three levels of government that secured the CDSA exemption and the funding to open Insite. The tale of these official negotiations and discussions has its own watershed moments as well as the drama of political careers lost and made. ${ }^{60}$ In comparison with the tale of the unofficial community actions that got the process off the ground, it is much more visible in the judicial analysis of "who has jurisdiction." It appears mostly in Pitfield J's trial judgment in the form of the many reports and analyses by governmental health authorities as the city and province began to study seriously, and then endorse, an experimental harm reduction strategy with Insite as its centrepiece. The provincial jurisdictional stake is, of course, explicitly represented in any constitutional dispute structured by the binary of federal and provincial governments. The next section of this essay turns to that division of powers framework and outlines the technical doctrinal aspects of the interjurisdictional immunity doctrine in relation to the Insite litigation.

As a postscript to the story sketched out above, I should add that the DTES harm reduction movement by no means dropped out of the picture once the more recognized channels of democratic change were activated. It continued to intervene before city council and to engage with decision-makers at all three levels of government. It also continued to pursue selfhelp strategies. In 2002, PHS, fearing that the momentum behind Insite at the governmental level would dissolve in impending municipal elections, decided to move ahead and open an unapproved safe injection site. It raised funds, and acquired and renovated a building that had been a sandwich shop. The new facility, now supposedly a hair salon, was outfitted with six injection booths. When it looked like Campbell, a harm reduction supporter, would in fact win the mayoral election, PHS shelved the effort in 
the hopes that an approved site would soon follow with better staffing and programming. ${ }^{61}$

Campbell did win and promised to open a facility by January 2003. But he soon found himself bogged down in governmental negotiations as well as coping with backlash from his endorsement of a massive crackdown by the Vancouver police on the open drug market in the DTES. Frustrated by the delays, Ann Livingston organized yet another illegal safe injection site, staffed by a volunteer nurse, that opened in April 2003, the day of the crackdown. ${ }^{2}$ It operated until Insite opened its doors in September at the location PHS had prepared earlier. At this point, it had official approval, was expanded to twelve booths, and had funds dedicated to staff and supportive programming.

\section{Part II: Interjurisdictional immunity doctrine before, during and after the B.C. Insite cases}

The interjurisdictional immunity doctrine, the basis of the Court of Appeal's majority decision in favour of Insite, is associated with the less favoured of two competing conceptions of interjurisdictional conflicts. The first conception uses the metaphor of watertight compartments to describe jurisdictional categories. It invokes for support the many references in the text of sections 91 and 92 in the Constitution Act, $1867^{63}$ to the exclusive nature of federal and provincial jurisdiction. In order to realize this commitment to exclusivity, the enumerations of "Matters" in the constitutional text are thought to mark out areas of jurisdiction that must be kept clearly differentiated from each other. Judges should strive to avoid any messy overlap or "leakage" from one "compartment" to another. While some overlap is inevitable, the interjurisdictional immunity doctrine delineates areas of exclusivity at the core of the legislative subject matters, whether or not the level of government with jurisdiction has actually used its power to enact a law. Valid laws enacted by the other level of government, but which spill over into this exclusive core can be rendered inapplicable under the doctrine, thereby maintaining the watertightness of the compartment.
An enthusiastic application of the interjurisdictional immunity doctrine would favour a generous delineation of the exclusive core and a softening of the standard used to measure whether a spillover is serious enough to warrant rendering a valid law inapplicable. Theoretically, the doctrine applies to protect both federal and provincial jurisdiction; however, in practice, it has heavily, if not exclusively, favoured the federal government. The interjurisdictional immunity doctrine, as well as the watertight compartments approach more generally, currently has a negative reputation, especially with judges at the Supreme Court of Canada. The negativity is rooted in the perception that the approach is rigid, inflexible, not "modern," and at odds with co-operative federalism. There is also a recurrent concern that the approach creates legislative "gaps" in the form of exclusive areas of jurisdiction in which the government that has jurisdiction has little incentive, or finds it difficult, to regulate. ${ }^{64}$

The competing approach, often described as "modern," treats messy overlaps between jurisdictional categories as not only inevitable but, to some extent, desirable. On this approach, courts will only intervene to clarify a jurisdictional dispute if there is a conflict between two valid laws serious enough to trigger the paramountcy doctrine. This doctrine always operates in favour of federal jurisdiction. An enthusiastic application of the modern approach would demand a very stringent test of conflict in order to trigger the doctrine, thereby tolerating a wider range of overlapping laws. Conversely, a watertight compartments approach to paramountcy would install a very low threshold test of conflict which, at provincial expense, would reduce the amount of overlap between federal and provincial regimes. The paramountcy doctrine, in the modern version, is perceived as being everything that the competing approach is not: elastic, flexible, modern, and facilitative of co-operative federalism. As such, it is viewed as more suited to the complexity of government in a contemporary federal state. Indeed, the Supreme Court of Canada has recently affirmed that it is both the preferred and dominant approach. ${ }^{65}$ 
PHS and VANDU turned to the courts for relief in 2008. In the preceding year, while Insite still had a short-term extension of its CDSA exemption, the Supreme Court of Canada decided a pair of cases, Canadian Western Bank $v$ Alberta $^{66}$ and British Columbia (Attorney General) v Lafarge Canada Inc ${ }^{67}$, that seemed to cement in place a "backseat" role for the interjurisdictional immunity doctrine in favour of a "front seat" role for the federal paramountcy doctrine. ${ }^{68} C W B$ concerned a claim of interjurisdictional immunity by a federally regulated bank in relation to a provincial insurance regime; Lafarge concerned a claim of immunity by the Vancouver Port Authority in relation to municipal zoning requirements. The Supreme Court of Canada rejected both claims. In $C W B$, Binnie and Lebel JJ wrote lengthy reasons, supported by four others, that redesigned the interjurisdictional doctrine. ${ }^{69}$ In Lafarge, Binnie and Lebel JJ again wrote reasons for the majority affirming the approach they had set out in $C W B{ }^{70}$

After noting in $C W B$ that the interjurisdictional immunity doctrine is inconsistent with the dominant trend in the jurisprudence, Binnie and Lebel JJ state that they wish to "make it clear that the Court does not favour an intensive reliance on the doctrine." ${ }^{\prime 1}$ They also direct that the indicia for its operation should be altered to make it harder to apply, specifying that it must be shown that the impinging legislation impairs rather than simply affects the vital and essential core of the other government's jurisdiction. The impairment standard is described as not quite as stringent as the "sterilize" test from early case law, but as more demanding than the "affects" test that has been the standard for several decades. ${ }^{72}$ Binnie and Lebel $\mathrm{JJ}$ also advise that it is preferable that courts resolve jurisdictional conflicts in new areas, if possible, with the doctrine of federal paramountcy. ${ }^{73}$

Despite these severe constraints on the doctrine's use and scope, the CWB analysis affirms that the doctrine is here to stay. Importantly for the Insite litigation, the judges note that application of the doctrine has been quite lopsided, in general protecting federally regulated entities from provincial regulation and not vice versa. The judges state that theoretically it should work both ways. Indeed, they observe that courts in the past have deployed the doctrine in the province's favour but have done so by simply limiting the federal legislation's ambit "without too much doctrinal discussion." 74 The implication is that, henceforth, courts should be more explicit about using the doctrine to protect core areas of provincial exclusive jurisdiction.

By and large, CWB contains the elaboration of the new approach. The companion case Lafarge, however, opens with the controversial assertion that the interjurisdictional immunity doctrine "should not be used where, as here, the legislative subject matter (waterfront development) presents a double aspect." 75 This statement is at the centre of the disagreement in the Insite litigation between the trial judge and the majority at the Court of Appeal. Pitfield J, the trial judge, took Binnie and Lebel JJ at their word. He found that the CDSA impairs a vital part of the provincial health care undertaking, Insite. However, because Insite operates in the double aspect field of health, Pitfield J felt compelled, following Lafarge, to resolve the conflict between the two levels of government in favour of the federal level under the paramountcy doctrine. ${ }^{76}$

Huddart JA at the Court of Appeal disagreed. She took heart from an article by Professor Robin Elliot in which he argues that Binnie and Lebel JJ could not have meant what they seem to have said in Lafarge. Professor Elliot points out that a new rule barring the use of the doctrine in double aspect fields would constitute a major transformation of the law, effectively eliminate the doctrine, and contradict much of what the two judges say in the companion case of $C W B$ as well as what they proceed to do in Lafarge-namely, analyse whether the Vancouver Port Authority can claim immunity in the double aspect field of waterfront development. ${ }^{77}$

Huddart JA in PHS Community Services Society would seem, then, to challenge judicial trends, first by making interjurisdictional immunity the centrepiece of her decision, second, by finding that the doctrine applies to protect a provincial entity from federal intrusions, and third, by refusing to accept at face value the statement in Lafarge that the doctrine has no 
role in double aspect fields. Her reasons, however, otherwise respect the parameters and spirit of the dominant approach by interpreting the requirements of the doctrine quite strictly. She accepts that the CDSA is valid criminal law but also makes clear that Insite's provision of medical treatment to its community is at the core of its purpose as a hospital and therefore at the core of provincial jurisdiction over hospitals. She maps that core very narrowly and precisely, fending off arguments that to give Insite the benefit of immunity would allow provinces to ignore federal narcotics legislation altogether or create legislative gaps with respect to the control of illegal drugs. At one point, she indicates that the application of the CDSA would "sterilize" essential and vital parts of Insite's operation as a hospital, suggesting that she is using a very high standard to determine whether the federal intrusion is sufficiently serious. ${ }^{78}$ For Huddart JA, co-operative federalism is facilitated rather than impeded by the interjurisdictional immunity doctrine because it allows breathing room for both the medical and criminal aspects of "the approach to the intractable problem [of] dangerous substances." 79 She finishes by asserting that if immunity is not available to Insite in this situation, "then it may well be said [despite $C W B$ 's remarks] the doctrine is not reciprocal and can never be applied to protect exclusive provincial powers." 80

Huddart JA's scepticism about the Lafarge statement has since found powerful support from the Supreme Court of Canada. Several months after the B.C. Court of Appeal decision, the Supreme Court of Canada returned to the subject of the interjurisdictional immunity doctrine in another pair of cases. Both emanate from Québec and concern federal jurisdiction, under its aeronautics power, over the construction of aerodromes, namely landing facilities for non-commercial aircraft. In Québec (Attorney General) v Canadian Owners and Pilots Association, ${ }^{81}$ the plaintiffs constructed an aerodrome on land zoned agricultural under Québec's scheme for the preservation of such land. The plaintiffs failed to obtain the required prior authorization for a non-agricultural use and, as a consequence, were ordered to return the land to its original state. McLachlin CJ wrote for a majority and found in favour of the aerodrome owners. She found that the aerodrome was a federally regulated undertaking, that the matter of its location lay at the core of federal jurisdiction, and that, as such, it was interjurisdictionally immune from the application of Québec's regime. In the course of her reasons, McLachlin CJ rejected Québec's argument, relying on Lafarge, that interjurisdictional immunity cannot apply in double aspect fields. McLachlin CJ asserted that such an interpretation of Lafarge is inconsistent with the approach set out in $C W B{ }^{82}$ and that Québec's argument is a "challenge to the very existence of the doctrine of interjurisdictional immunity," a position that is inconsistent with the constitutional text and its many references to the exclusivity of legislative jurisdiction as well as precedent. ${ }^{83}$

In $C O P A$, Binnie and Lebel JJ take different paths. ${ }^{84}$ However, the divergence does not undermine the basic elements of their reasons in $C W B$. The crux of McLachlin CJ's majority reasons, with which Binnie J agreed, is her finding that the impact of Québec's agricultural land reserve scheme on federal jurisdiction meets the $C W B$ standard of impairment. She reaches this conclusion even though the federal scheme leaves the location and development of aerodromes to the private market. For McLachlin CJ, the option of relying on private ordering in this way lies at the core of Parliament's aeronautics power and is impaired by Québec's decision to legislatively protect its agricultural lands from the operation of the market. ${ }^{85}$

Lebel J, in a very short dissent, agrees that the location of an aerodrome by Parliament is an essential and core aspect of its jurisdiction, but argues that the location of an aerodrome by a private company is not. The implication is that, for Lebel J, the question of impairment is irrelevant as there has been no intrusion at all into an exclusive area of federal jurisdiction. ${ }^{86}$ Thus, the disagreement between Binnie and Lebel JJ would appear to be over how narrowly to map the exclusive core that can potentially be protected by the immunity doctrine's impairment test. Lebel J's restrained approach to this task would seem to be more in keeping with the caution advised by $C W B$ as well as with the 
concern it expressed about an asymmetry that favours federal power.

In the companion case, Québec (Attorney General) $v$ Lacombe, ${ }^{87}$ McLachlin CJ again wrote reasons in favour of the aerodrome owners for a majority that included Binnie J but not Lebel J, and, again, the divergence between the two judges does not point to a major fault line. ${ }^{88}$ However, Deschamps J's comments in her dissent in Lacombe may have a direct bearing on the Insite litigation. Deschamps J at one point criticizes McLachlin CJ for suggesting in COPA that the interjurisdictional immunity doctrine only protects core areas of federal jurisdiction, a stance she argues is inconsistent with $C W B$ and with the principle of subsidiarity. While McLachlin CJ's reasons in both COPA and $L a-$ combe discuss the doctrine only in relation to federal jurisdiction, she does not actually state that it can only protect federal exclusivity. ${ }^{89}$

In short, this most recent foray by the Supreme Court of Canada into the interjurisdictional immunity doctrine affirms that $C W B$ is the governing framework. It also affirms that the doctrine still has a role to play despite its less favoured position. In particular, McLachlin CJ's majority reasons in COPA support Huddart JA's view in PHS Community Services Society $(B C C A)$ that the interjurisdictional immunity doctrine can be an important tool for resolving conflicts that arise in the context of double aspect subject matters such as health. Finally, Deschamps J's comments in Lacombe raise a question about whether interjurisdictional immunity protects provincial as well as federal jurisdiction.

\section{Part III: Complicating democracy in federalism jurisprudence}

The above summary touches on the key aspects of the interjurisdictional immunity analysis that are at play in the Insite litigation. There are additional doctrinal questions raised by the case and by the recent jurisprudence. For example, are there any solid precedents supporting the application of the doctrine to entities lying within provincially regulated areas of jurisdiction? Or, is an application in favour of provincial power, if that is still a possibility after the aerodrome cases, a new area and thus one that must, if possible, be settled under the federal paramountcy doctrine? Does the impairment test measure interference with the operation of the entities in question-aerodromes, port authorities, banks, safe injection sites - or with the integrity of the relevant government's exclusive jurisdiction? And, hovering in the background of these questions about the post- $C W B$ approach is the larger question of the stability of the view, endorsed by $C W B$, that a modern approach that relies on the paramountcy doctrine to resolve interjurisdictional conflicts is the dominant and better approach and that the interjurisdictional immunity's less favoured watertight compartments approach should be confined to a minor role. McLachlin CJ's readiness in COPA, just three years after $C W B$, to give the immunity doctrine quite a generous scope, albeit in favour of the federal government, may rehabilitate the doctrine somewhat, although one would hope not in its typically asymmetrical form.

Some scholars reject the idea that one approach is better than the other or that functional considerations such as flexibility and efficiency should figure so prominently in adjudication of federal conflicts. Bruce Ryder and Robin Elliot, for example, argue that while both approaches present dangers, both are essential to a workable federalism jurisprudence..$^{90}$ Ryder in particular argues for a more values-based analysis of federalism conflicts. He is critical of a historical pattern of deploying the interjurisdictional immunity doctrine to pursue goals that lie outside the purview of adjudication, such as the pursuit of a deregulatory agenda with respect to markets. ${ }^{91}$ Nonetheless, he argues that the doctrine, and the watertight compartments view more generally, is crucial to the realization of key constitutional values that underlie and animate the constitutional text setting out the division of powers-values that are properly within the purview of judges. He discusses in particular the principles of provincial autonomy, recognition of indigenous polities, and democracy. ${ }^{92}$

PHS Community Services Society (BCCA) would seem to engage at least two of these values-provincial autonomy and democracy. Pro- 
vincial autonomy is clearly at the forefront of Huddart JA's analysis. She is adamant that both the local nature of the crisis, and the constitutional commitment to exclusive areas of provincial jurisdiction-evident in both the text of the Constitution and the jurisprudence-directs a finding of provincial immunity from the application of the CDSA to Insite. Democracy does not feature in the same central way; however, it is implicit, given the jurisprudential understanding that federalism and democracy are inextricably intertwined. The Supreme Court of Canada has assured us that the principle of federalism configures "different and equally legitimate majorities in different provinces and territories and at the federal level." ${ }^{\text {"3 }}$ And a key reason for rejecting interjurisdictional immunity is the "legislative gap" argument, namely that it mars the otherwise seamless and exhaustive distribution of legislative powers to democratically elected governments by creating, at a functional level, little pockets of exclusive jurisdictional space where one government's laws are inapplicable and the other government finds it difficult or uninviting to legislate. ${ }^{94}$

Huddart JA's reasons adhere diligently to these conceptions of the interrelation between federalism and democracy. She denies that any gaps would be created by according interjurisdictional immunity to the Province's health care undertaking Insite. For her, the "gap" we should be worried about is the one that would be created if the Province, the only government with authority to respond to the local health crisis in the DTES, was prevented from doing so by the paramountcy of federal narcotics legislation. ${ }^{95}$

At a more fundamental level, however, the key communities for Huddart JA are necessarily those marked out by formal representative processes and institutions, as well as by the formal apparatus of government: ministries, health authorities, and Insite itself-a "hospital" that is explicitly assigned to provincial jurisdiction by section 92(7) of the Constitution Act, 1867. Only her references to the "local" and to the principle of subsidiarity gesture in the direction of a more substantive understanding of democracy and autonomy. ${ }^{96}$ Indeed, the "people" in her decision do not show up as active political agents other than very indirectly. Rather, the "people," in the story she tells, are most vividly present as patients desperately in need of the health services provided by the provincial governmental apparatus.

The "people" of course also show up as individuals in the Charter analyses. Rowles JA notes the PHS Society's self-description as representing "those who are homeless or at risk of homelessness due to multiple barriers to stable housing associated with a combination of unemployment, addiction, chronic illness and mental health problems." ${ }^{\prime 9}$ As well, she notes the evidence of a demographic survey of 1,000 users that shows high proportions of persons with infectious disease (87\% have Hepatitis C; $17 \%$ have HIV); of aboriginal persons (18\%); of sex trade workers (38\%); and of the homeless (20\%). ${ }^{98}$ These figures assist in demonstrating the vulnerability of the individuals who are claiming an unconstitutional interference with their life, liberty, and security of the person. Similarly, Pitfield J at trial and Smith JA, in her dissent at the Court of Appeal, focus in their analyses of the section 7 interests in life and security of the person, on the medical vulnerabilities of Insite clients in terms of risks to life and health from overdose and infectious diseases.

For these three judges, then, the compelling justice issue has to do not with the autonomy of the relevant political community or with democracy, but with the fundamental entitlement of individuals, including those suffering from the illness of addiction, to live a life with dignity. Hence, the Charter rights framework works best for them. Social groups that are defined by disadvantage-homelessness, addiction, illness-are implicitly referenced, but only to give a more textured account of the key political actor in liberal rights discourse, namely, the individual. In short, a discourse of rights that presents individual claimants as "injured" in multi-dimensional and intersecting ways is strategically compelled by the Charter lens. ${ }^{99}$

Both the rights and division of powers narratives tell important stories about singular and significant dimensions of our political community. However, they are distinctly different narratives and only the jurisdictional frame, 
I would suggest, can get at the concerns about democracy. Indeed, some would argue that the rights frame in some respects "fences" us into the sites of our subordination, thereby reproducing that subordination ${ }^{100}$ and deflecting from "the dream of democracy-that humans might govern themselves by governing together." 101 I understand, however, why, intuitively, the narrative about rights seems to get closer to our sense of the compelling issue of justice in the story of Insite. The jurisprudential story of intergovernmental relations, with its high level of abstraction and technicality, appears detached and removed, perhaps pathologically so, from the pain and urgency of the situation. Our judges, law teachers and legal scholars assure us that the vocabulary of immunities and vital parts, and the bewildering distinctions between sterilization, impairment, and effects, are really about the integrity of our democratic processes, the accountability of governments to the configuration of the "people" into various majorities, and the autonomy and self-government of the multiple polities that constitute our federal system. But it takes several analytical leaps to draw those connections, and in the end, frankly, we are still left with a very formal, procedural conception of the democratic political community-namely as a collection of voters configured into various territorial, provincial and national majorities.

I want to argue that there is another narrative about democracy and political community that although it has very little, if any, purchase in our constitutional texts and jurisprudence, might productively instill in them a deeper democratic logic. This narrative takes the "difference" that federalism protects out of its formal governmental container and locates it closer to the ground in an activist, "critical oppositional politics." 102 The model is Iris Marion Young's conception of democratic politics. Young urges us to embrace a theory of democracy that has a place for both reasoned deliberation within the institutional channels of representative government and established civil society institutions and a more "rowdy, disorderly and decentred politics." 103 The latter, importantly, persists in challenging the constraints imposed by public and private institutions on the terms of social change and on our imagined possibilities. Such institutions, although crucial to a functioning democracy, are inherently shaped by their historical evolution under and current positioning in relation to conditions of structural inequality. ${ }^{104}$

Young's point is echoed in Wendy Brown's discussion of the conundrum of formulating a post-individualist conception of democratic freedom, and in James Tully's insistence that such freedom entails both rule of law and a practice of self-rule. Brown observes that freedom, when institutionalized, tends to reinstall the particular practices of domination that it has vanquished. ${ }^{105}$ Hence, she advises, freedom would seem to "depend on a formulation of the political that is richer, more complicated, and also perhaps more fragile than that circumscribed by institutions, procedures and political representation." ${ }^{106}$ James Tully, similarly, urges us to embrace an expansive conception of democracy that both affirms and goes beyond eighteenth-century conceptions of formal representative institutions to include "any activity in which people assemble and negotiate the way and by whom power is exercised over them."107 Like Young, Tully argues that field of democratic politics must extend to include the full range of approaches to dialogue, deliberation, and "decision making interaction." 108

The story of Insite illustrates Young's concern that the abiding conditions of structural inequality under which our representative institutions have evolved place significant limits on our political possibilities. Key institutional actors in 1993 assumed that the starting point for a response to the addiction crisis was a combination of the enforcement measures and abstinence-based treatments that had evolved over a number of years under the rubric of the "war on drugs." The options within this frame ranged from more effective enforcement-more police officers on foot patrol, for example-to better ways to achieve abstinence-more facilities and resources for detox, for example. It took several years of direct action in the form of demonstrations such as the "thousand crosses" demonstration, the creation of illegal safe injection sites, the setting up of unfunded drop-in 
centres, the convening of meetings in the park, and the institution of needle exchanges and back-alley patrols, to begin to shift perceptions in both enforcement and health care circles toward a wider set of possibilities. And after all that, the shift in the end, although significant, was relatively modest, consisting of a commitment to explore harm reduction strategies on an experimental basis for research purposes alongside enforcement and abstinence-based treatment. ${ }^{109}$

Young also urges that we create space for a critical oppositional politics because of its disruption of hegemonic discourses that, under conditions of structural inequality, render the conditions of that inequality as natural or inevitable features of life. Such discursive constraints on social and political change operate in a more subtle way, placing limits on the possible at a normative and conceptual level. ${ }^{110}$ In the story of Insite, a discursive or ideological obstacle to change has been and continues to be the notion of choice, and the conflation of freedom with individual choice. ${ }^{111}$ Despite a wealth of evidence supporting the characterization of addiction as a disease with multiple social, psychological, and genetic causes, the conviction that addiction is fundamentally a reprehensible personal choice for which, ultimately, individual addicts must accept responsibility remains difficult to dislodge. It is at the core of the federal government's argument in PHS Community Services Society that any addiction-related threat, in the form of death by overdose or infectious disease, posed to the Charter-protected interests in life, "results from an individual's choice to inject a harmful and dangerous narcotic rather than state action." 112

There is little rhetorical space in our division of powers analysis to give texture to the democratic claims of the DTES user community and its grassroots harm reduction movement. The DTES user community simply is not cognizable as a political community in the legal, constitutional discourse of self-government. There are only two places in our jurisprudence that hint at what a more substantive and textured understanding of the principle of democracy might entail. The first is in the very brief references in the case law to subsidiarity. The second is in the more extensive jurisprudence concerning division of powers conflicts in which the community standing behind the federal side of the conflict is an indigenous community.

The principle of subsidiarity surfaces in Canadian jurisprudence simply as a gesture, as in PHS Community Services Society (BCCA) itself. ${ }^{113}$ The most oft-cited instance of this is in 114957 Canada Lteé (Spraytech, Société d'arrosage) $v$ Hudson (Town) in which L'Heureux-Dube J, writing for the majority, begins the decision by asserting that "matters of governance" in the current era are "often examined through the lens of the principle of subsidiarity." 114 She then defines subsidiarity as "the proposition that law-making and implementation are often best achieved at a level of government that is not only effective, but also closest to the citizens affected and thus most responsive to their needs, to local distinctiveness, and to population diversity."115 Spraytech involved a challenge to a municipal bylaw that imposed conditions on pesticide use that were more onerous than those in place at either the provincial or federal levels. L'Heureux-Dube J's majority reasons found in favour of the municipality and, in doing so, accorded the municipal level of government a broad power to act in the interest of the general welfare. ${ }^{116}$

Although there is a reaching out to difference "on the ground" in the form of the lived experience of communities in L'Heureux-Dube J's articulation of subsidiarity and her willingness to extend the principle to municipalities, it is still a principle framed in terms of formal "levels" of government. ${ }^{117}$ Thus, it does not contemplate the sorts of processes and oppositional politics that unfolded around the establishment of Insite. Moreover, recent comments in a decision by the Supreme Court of Canada seem aimed at minimizing any role subsidiarity might have. In Reference Re Assisted Human Reproduction Act, a plurality of four judges in reasons set out by McLachlin CJ firmly rejects the notion that the principle of subsidiarity requires that "the criminal law must be circumscribed in order to preserve space for provincial regulation" of health care. ${ }^{118}$ 
The second example pertains to indigenous communities who have turned to the language of division of powers in pursuing their right to decide issues that bear directly on their survival as communities. The cases take the form of a claim that the federal government, by virtue of its constitutional jurisdiction over "Indians and Lands Reserved for Indians"119 is immune from the operation of provincial laws, or, alternatively, that provincial laws are rendered inapplicable under the federal paramountcy doctrine. A claim of interjurisdictional immunity best achieves the underlying objective as it creates a jurisdictional space that, if uninhabited by federal laws, can be occupied in a de facto manner by indigenous legal orders.

Perhaps the most famous in this line of cases is Natural Parents $v$ Superintendent of Child Welfare et al, ${ }^{120}$ in which the Tsartlip community unsuccessfully sought to resist the adoption under provincial law of a Tsartlip child by a non-indigenous couple. The argument was that interjurisdictional immunity applied because Indian child and family relationships lie at the exclusive core of federal jurisdiction, or alternatively, that the federal legislation with respect to Indians is paramount and rendered the provincial law inapplicable. At stake was not simply the adoption of the particular child in accordance with Tsartlip customary law, but the intergovernmental arrangement between federal and provincial governments that set in motion the infamous "sixties scoop," namely the apprehension of disproportionate numbers of indigenous children under provincial child welfare legislation and their placement in and, in many cases, adoption by, non-indigenous families.

Ryder argues that courts should apply an "autonomist" approach to such cases, one that employs the "doctrinal techniques" of the watertight compartments approach, including the interjurisdictional immunity doctrine and an extremely broad "covering the field" interpretation of the paramountcy doctrine, to safeguard an area of sovereignty for indigenous communities. ${ }^{121}$ As Ryder points out, this would require a radical change in current case law which presumes that section 91(24) confers plenary juris- diction on the federal level of government over indigenous peoples rather than a responsibility to respect and support indigenous autonomy. ${ }^{122}$ Indeed, Ryder notes that the case law provides little hope that such a shift is likely. However, the factual records in these cases-detailing claims with respect to customary adoption norms, hunting practices, spiritual practices, and child welfare-invite us to take seriously the indigenous claim to autonomy and to challenge the idea that a "legislative gap" necessarily means an absence of self- government. In short, in these cases, as in PHS Community Services Society, one can glimpse through the interstices of the jurisprudence the possibility of an alternative constitutional approach that nevertheless builds on fundamental constitutional principles.

\section{Conclusion}

The purpose of this essay is to argue that we need to expand the range of factors that courts look at in settling interjurisdictional disputes with respect to the constitutional division of powers. Courts, in the large run of cases, are necessarily and properly constrained to examine such disputes in terms of formal levels and institutions of representative government. However, the deeper principles that animate our constitutional texts invite a more textured analysis, in particular with respect to the principle of democracy. The story of Insite presents us with a situation in which injection drug users' survival and health were at stake and in which users as a group faced deeply embedded systemic and discursive barriers to participation within the conventional channels of democratic deliberation and change. In the face of this, the community pursued institution-building projects, peer support strategies, media interventions to "talk back" to demonizing discourses and to dislodge political indifference, and the creation of alternative fora (the weekly user meetings, direct action and protests) for deliberative democratic engagement. My argument is that a judicial determination of where jurisdictional authority resides in a democratic polity-a decision that is at base one about the structure of self-government-should take account of 
these elements of functional self-government or "democracy on the ground." The need to do so is particularly compelling where a social group, for reasons of structural inequality, has very little purchase in representative politics and where, as in the case of Insite, the interest at stake is of a significant and fundamental nature.

As I have developed this argument, admittedly in a preliminary way, I have been very conscious of feminist concerns regarding the interjurisdictional immunity argument in support of Insite. The concern is that the same template applied in the context of some provincial decisions about abortion clinics would produce decidedly less progressive results, essentially erasing instead of acknowledging political space for the critical oppositional politics engaged in by the women's movement. In the abortion context, the characterization of provincial regulatory opposition to abortion clinics as essentially intruding upon federal jurisdiction under its criminal law power has, strategically, been crucial to ensuring women's access to abortion. ${ }^{123}$ However, my argument is not that interjurisdictional disputes should be more sensitive to and textured by local politics simply because they are local. Rather, my point is that the analysis of such disputes should be more sensitive to and textured by critical oppositional politics and by the democratic engagement of politically marginalized groups that takes place outside established channels of power. ${ }^{124}$ Such a politics can as easily point in the direction of federal as well as provincial jurisdiction. What is crucial is that the premise of political marginality requires some attention to actual relations of power and to political voice. As well, such oppositional politics must be weighed in relation to the constraints implicit in the norms of publicity and openness that underpin political communication in a democracy, namely that any claims must "not [be] uttered in a way that others could not accept as consistent with their own worth and dignity." 125

The mobilization of the harm reduction movement by the user community in the DTES is a striking example of grassroots oppositional politics by a group that is structurally and discursively marginalized. Furthermore, the tex- turing of the jurisprudence of jurisdiction with acknowledgement of such political engagement might provide the ground on which we could begin to recognize urban communities such as the DTES as "unsettled" neo-colonial spaces that demand a more sophisticated calculus of democratic self-government than the simplistic and formal federal-provincial binary provides. ${ }^{126} \mathrm{In}$ short, I agree with Ryder and Elliot that we need more, not fewer, conceptions of how federalism and complex jurisdictional arrangements work. My suggestion that courts should require argument and evidence that explicitly complicate, in this manner, the democratic principles at stake in jurisdictional disputes would be a modest step in that direction.

Judges, understandably, are loath to relinquish the solid ground of textual truths and objective principles. I am by no means arguing that these traditional guides to interpretation should be jettisoned. Judges, after all, are appropriately concerned not simply with the legitimacy of representative institutions, but with their own legitimacy within a broader democratic framework. Text and abstract principle often seem to provide the clearest foundation for judicial legitimacy. However, this is to assume that legitimacy exists in a vacuum, that it has a kind of self-referential coherence that can ignore the context of the deeply engrained and persistent legacy of colonialism as well as pervasive "class inequality, residential segregation, and gender division of labour."127 In short, attention to critical oppositional politics and its recognition as a fundamental and necessary component of democratic engagement is invited rather than foreclosed by our constitutional texts and principles.

\section{Notes}

* Professor, Faculty of Law, University of Victoria.

1 SC 1996, c 19 s 56 [CDSA].

2 The BC Civil Liberties Association, the Vancouver Coastal Health Authority, and the Dr. Peter AIDS Foundation also intervened with the Province.

3 Canadian Charter of Rights and Freedoms, Part I of the Constitution Act, 1982, being Schedule B 
to the Canada Act 1982 (UK), 1982, c 11, s 7 [the Charter]: "7. Everyone has the right to life, liberty and security of the person and the right not to be deprived thereof except in accordance with the principles of fundamental justice."

42008 BCSC 661, 293 DLR (4 $\left.4^{\text {th }}\right) 392$ [PHS Community Services Society (BCSC)].

52010 BCCA 15, 314 DLR (4 $\left.{ }^{\text {th }}\right) 209$ [PHS Community Services Society (BCCA)].

6 Supreme Court of Canada, Scheduled Hearings, online: Supreme Court of Canada <http://www. scc-csc.gc.ca/case-dossier/cms-sgd/hear-aud-eng. aspx? $\mathrm{ya}=2011 \&$ ses $=03 \&$ sr $=$ Search $>$.

7 See the work of Reva Siegel, for example, "Roe's Roots: The Women's Rights Claims that Engendered Roe" (2010) 90 BUL Rev 1875, and "Constitutional Culture, Social Movement Conflict, and Constitutional Change: The Case of the Defacto ERA" (2006) 94 Cal L Rev 1323; William Eskridge, "Some Effects of Identity-Based Social Movements on Constitutional Law in the Twentieth Century"(2002) 100 Mich L Rev 2062; Miriam Smith, Lesbian and Gay Rights in Canada: Social Movements and Equality-Seeking, 1971-1995 (Toronto: University of Toronto Press, 1999); and Christopher Manfredi, Feminist Activism in the Supreme Court: Legal Mobilization and the Women's Legal Education and Action Fund (Vancouver: University of British Columbia Press, 2004).

8 Nicholas Blomley, Unsettling the City: Urban Land and the Politics of Property (New York: Routledge, 2004) at 34.

$9 \quad$ Ibid at 108.

$10 \quad$ Ibid at 131.

11 The $10 \%$ figure, which does not include homeless persons or the large numbers who visit on a daily basis, is found in City of Vancouver, 2005/06 Downtown Eastside Community Monitoring Report, $10^{\text {th }} \mathrm{ed}$, online: City of Vancouver $<$ http://vancouver.ca/commsvcs/planning/dtes/ pdf/2006MR.pdf> [Monitoring Report]. This is the most conservative figure. Others estimate the indigenous population at 37 to $40 \%$. See J Cain, Report of the Task Force into Illicit Narcotic Deaths in British Columbia (Victoria: Ministry of the Attorney General, 1994), cited in Larry Campbell, Neil Boyd and Lori Culbert, A Thousand Dreams: Vancouver's Downtown Eastside and the Fight for Its Future (Vancouver: Greystone Books, 2009) at 55. Adrienne L Burk notes that the DTES is "widely acknowledged in Canada as having one of the largest off-reserve concentrations of Aboriginal peoples of various First Nations" in Speaking for a Long Time: Public
Space and Social Memory in Vancouver (Vancouver: University of British Columbia Press, 2010) at xi. Blomley, supra note 8 at 113 observes that in 2001 half of all indigenous people in Canada were urban.

12 Burk, supra note 11 at 157.

13 Campbell, Boyd and Culbert, supra note 11 at 56. The authors recount Lou Demerais, an activist on Native health issues in the DTES, "telling Aboriginal people they needed to start voting in elections so that politicians would listen. 'But they had so many more other issues to struggle with-sickness, housing, eating...."'

14 Monitoring Report, supra note 11 at 10.

15 Ibid at 8.

16 Ibid.

17 Ibid at 12.

$18 \quad$ Ibid at 13.

19 Leslie Robertson and Dara Culhane, In Plain Sight: Reflections on Life in Downtown Eastside Vancouver (Vancouver: Talonbooks, 2005) at 13-14.

20 "Laurie" in Robertson and Culhane, ibid 36 at 60. In an effort to counteract the invisibility of the missing women as individuals, painter Betty Kovacic created an exhibition of mixed media portraits of the first fifty women to disappear. Kovacic hoped that the exhibition would "accomplish, in part, what the missing women could not achieve in life." She wrote of her project: "I trust that each viewer will look into the face of each woman long enough to really 'see' her, acknowledge her individuality, and embrace our common humanity." Betty Kovacic, A Roomful of Missing Women (Prince George: Two Rivers Gallery, 2007) at 1.

21 Leslie Robertson, "Taming Space: Drug use, HIV, and homemaking in Downtown Eastside Vancouver" (2007) 14:5 Gender, Place \& Culture 527 at 528.

22 Adrienne Burk notes that "the Downtown Eastside has until recently been the second most stable neighbourhood in Vancouver, after the elite enclave of Shaugnessy." Burk, supra note 11 at $\mathrm{x}$.

23 Blomley, supra note 8 at xiv.

24 Ibid at 51.

25 Ibid at 53-65.

26 Burk, supra note 11 at 157.

27 Campbell, Boyd and Culbert, supra note 11 at 43.

28 Donald MacPherson, Zarina Mulla, Lindsey Richardson, "The Evolution of Drug Policy in Vancouver, Canada: Strategies for Preventing Harm from Psychoactive Substance Use" (2006) 17 International Journal of Drug Policy 127 at 
127.

29 Ibid

30 Dan Small, Anita Palepu, and Mark W Tyndall, “The Establishment of North America's First State Sanctioned Supervised Injection Facility: A Case Study in Culture Change" (2006) 17 International Journal of Drug Policy 73 at 73-75.

31 MacPherson, Mulla and Richardson, supra note 28 at 129; Susan C Boyd, "The Journey to Compassionate Care: One Woman's Experience with Early Harm-Reduction Programs in BC" in Susan C Boyd and Lenora Marcellus, eds, With Child: Substance Use During Pregnancy: A Woman-Centred Approach (Halifax: Fernwood 2007), 10 at 14-15.

32 Campbell, Boyd and Culbert, supra note 11 at 45.

33 Turvey worked with, Downtown Eastside Youth Activities Society (DEYAS). Ibid at 45-46.

34 Boyd, supra note 31 at 10.

35 Ibid at 14.

36 Ibid at 10.

37 Campbell, Boyd and Culbert, supra note 11 at 51, 127.

38 PHS Community Services Society (BCSC), supra note 4 at paras 22-23.

39 Vince Cain, the Chief Coroner of B.C., released a report in 1994 that pronounced the war on drugs a failure and called for harm reduction strategies, including safe injection supervision, and highlighting, in particular, the impacts of addiction on indigenous residents in the DTES. It was several years before government officials heeded Cain's recommendations. See MacPherson, Mulla and Richardson, supra note 28 at 127-28 and Campbell, Boyd and Culbert, supra note 11 at 51, 55.

$40 \quad$ Ibid at 62-63.

41 Susan Boyd, Donald MacPherson, and Bud Osborn, Raise Shit! Social Action Saving Lives (Halifax: Fernwood, 2009) at 19; and Campbell, Boyd and Culbert, supra note 11 at 108-10. Thomas Kerr et al, Responding to an Emergency: Education, Advocacy and Community Care by a Peer-Driven Organization of Drug Users: A Case Study of Vancouver Area Network of Drug Users (Ottawa: Health Canada, 2001) at 6.

43 Boyd, MacPherson and Osborn, supra note 41 at 44.

44 Ibid at 43; and Campbell, Boyd and Culbert, supra note 11 at 111 .

45 Kerr et al, supra note 42 at 9.

46 Ibid at 11; and Vancouver Area Network of Drug Users, online: <http://www.vandu.org >.

47 Boyd, MacPherson and Osborn, supra note 41 at 43.
Ibid at 84-85.

Ibid at 102 .

Ibid at 51.

Ibid at 59.

Ibid at 45-62.

Kerr et al, supra note 42 at 9-10, 12-14, 24-26.

Ibid at 17.

These figures were provided in 2001 by VANDU staff who based them on attendance at meetings. See ibid at 13 . The figures roughly parallel the demographic make-up of the neighbourhood discussed at supra note 11.

Shared Learnings on Homelessness, Portland Hotel Society, online: <http:// www.sharedlearnings.org/index. cfm?fuseaction=Prof.dspProfileFull\&profiles $\mathrm{id}=18131194-83 f f-4 f 31-a e a 0-37 e 8756 b 3 d 0 e>$.

Campbell, Boyd and Culbert, supra note 11 at 91. Ibid at 127.

Boyd, MacPherson and Osborn, supra note 41 at 95-96, quoting Jim McNulty, "Death toll mounts while government searches for votes" The Province (July 22, 1998).

Mayor Philip Owen lost the support of his party because of his commitment to a framework that included consideration of harm reduction strategies. Larry Campbell became the next mayor, winning on the basis of his commitment to continue with Owen's plan. Campbell, Boyd and Culbert, supra note 11 at 166-70.

Ibid at 173-74.

Ibid at 181-82. Constitution Act, 1867 (UK), 30\&31 Vict, c 3, reprinted in RSC 1985, App II, No 5.

Canadian Western Bankv Alberta, 2007 SCC 22, [2007] 2 SCR 3 at paras 42, 44, Binnie and Lebel $\mathrm{JJ}[\mathrm{CWB}]$.

Ibid at paras 36, 37 and 69.

Ibid.

2007 SCC 23, [2007] 2 SCR 86 [Lafarge]. $C W B$, supra note 63 at para 47.

The four other judges were McLachlin CJ and Fish, Abella and Charron JJ A seventh judge, Bastarache J, concurred in separate reasons and on generally the same grounds, but without revamping interjurisdictional immunity doctrine.

70 In this case, Binnie and Lebel JJ wrote reasons for a majority composed of Deschamps, Fish, Abella and Charron JJ Bastarache J wrote concurring reasons.

CWB, supra note 63 at para 47.

Ibid at para 48 .

Ibid at para 78 .

Ibid at para 35.

Lafarge, supra note 67 at para 4, cited by Pitfield 
J in PHS Community Services Society (BCSC), supra note 4 at para 118.

PHS Community Services Society (BCSC), supra note 4 at paras 117-18.

PHS Community Services Society (BCCA), supra note 5 at paras 151-53, referring to Robin Elliot's discussion of Lafarge in "Interjurisdictional Immunity after Canadian Western Bank and Lafarge Canada Inc.: The Supreme Court Muddies the Doctrinal Waters-Again" (2008) 43 SCLR $\left(2^{\text {nd }}\right) 433$ at $480-81$.

PHS Community Services Society (BCCA), supra note 5 at para 168.

Ibid at para 171.

Ibid at para 176.

2010 SCC 39, [2010] 2 SCR 536 [COPA].

Ibid at para 55.

Ibid at para 58.

The majority was composed of McLachlin CJ and Binnie, Fish, Abella, Charron, Rothstein and Cromwell JJ Lebel and Deschamps JJ each wrote dissenting reasons.

COPA, supra note 81 at paras 50-53.

Ibid at para 77. Deschamps J's dissent turns on her finding that the impact of the provincial scheme on the federal aeronautics power does not meet the CWB impairment standard. Ibid at para 90 .

2010 SCC 38, [2010] 2 SCR 453 [Lacombe]. McLachlin CJ finds that the municipal zoning regulation that would prohibit the construction of an aerodrome is an ultra vires invasion of the federal power over aeronautics that cannot be sustained under the ancillary powers doctrine. Ibid at paras 30,58 . Thus, there is no need to address immunity or paramountcy arguments. Lebel $\mathrm{J}$ in separate and very short reasons also finds in favour of the aerodrome owners but on the grounds of paramountcy doctrine. Ibid at para 70. Deschamps J in dissent, finds, like Lebel $\mathrm{J}$, that the bylaw is valid and non-impairing but would also find that paramountcy doctrine is not triggered. Ibid at paras 148, 181.

Deschamps J, ibid at para 109 cites para 43 of McLachlin CJ's reasons in COPA when describing Mclachlin CJ's position in this regard.

Bruce Ryder, “The Demise and Rise of the Classical Paradigm in Canadian Federalism: Promoting Autonomy for the Provinces and First Nations" (1990-91) 36 McGill LJ 308 at 313, 380-81; and Robin Elliot, supra note 77 at 482-90.

Ryder, supra note 90 at 321, 327-39.

Ibid at 322.

Reference Re Secession of Québec, [1998] 2 SCR 217, 161 DLR (4th) 385 at para 66.

9$$
\text { "fixe }
$$
ing as social positions, and codifies as well the meanings of their actions against all possibilities of indeterminancy, ambiguity, and struggle for resignification or repositioning." States of Injury: Power and Freedom in Late Modernity (Princeton: Princeton University Press, 1995) at 27. See, however, Colleen Sheppard, Inclusive Equality: The Relational Dimensions of Systemic Discrimination in Canada (Montréal: McGill-Queen's University Press, 2010) at 119-35 for a thoughtful analysis of how principles of democracy can and should inform equality rights.

100 Wendy Brown, "Suffering the Paradoxes of Rights" in Wendy Brown and Janet Halley, eds, Left Legalism/Left Critique (Durham, NC: Duke University Press, 2002), 420 at 422, 431.

101 Brown, States of Injury, supra note 99 at 5.

102 Iris Marion Young, "Activist Challenges to Deliberative Democracy" (2001) 29:5 Political Theory 670 at 671. See also Inclusion and Democracy (Oxford: Oxford University Press, 2000) at 48-49.

103 Young, "Activist Challenges," supra note 102 at 688.

104 Ibid at 683-84.

105 Brown, States of Injury, supra note 99 at 8.

106 Ibid at 9.

107 James Tully, Public Philosophy in a New Key: Democracy and Civic Freedom, vol 1 (Cambridge: Cambridge University Press, 2008) at 157.

108 Ibid at 308.

109 The endorsement in 2001 by the City of Vancouver of a four-pronged strategy aimed at prevention, treatment, enforcement and harm reduction included traditional as well as non-traditional responses to addiction and injection drug use. Subsequently, the Vancouver Coastal Health authority undertook a supervised injection site initiative, culminating in the approval of a CDSA exemption from the federal government. $P H S$ Community Services Society (BCSC), supra note 4 at paras 33-46. The exemption was granted based on "the necessity for scientific purpose." $P H S$ Community Services Society (BCCA), supra note 5 at para 10 . 
110 Young, "Activist Challenges," supra note 102 at 685-87. Again, Young's point is echoed in Tully's argument, in the context of norms of mutual recognition, that such norms must always be open to contest and dialogue because any agreement will always be flawed: "There are always asymmetries in power, knowledge, influence and argumentative skills that block the most oppressed from getting to negotiations in the first place and then structuring the negotiations if they do." Tully, supra note 107 at 306.

111 Brown, States of Injury, supra note 99 at 13. Brown here is critiquing thinkers on the left who, in the wake of the atrocities of "actually existing socialisms" have abandoned a critique of capitalism in favour of the idea that "freedom, finally, is a matter of consumption, choice, and expression: an individual good rather than a social and political practice." Ibid.

112 PHS Community Services Society (BCSC), supra note 4 at para 141.

113 PHS Community Services Society (BCCA), supra note 5 at para 123.

1142001 SCC 40, [2001] 2 SCR 241 [Spraytech] at para 3. Gonthier, Bastarache and Arbour JJ agreed with L'Heureux-Dubé J's reasons. Lebel J wrote concurring reasons with which Iacobucci and Major JJ agreed.

115 Ibid.

116 Ibid at para 29.

117 It should be noted that the principle has historically been invoked to demand deference to sub-political associations and social groups such as churches and guilds. Robert Howse, "Subsidiarity in All but Name: Evolving Concepts of Federalism in Canadian Constitutional Law" in Contemporary Law, 1994: Canadian Reports to the 1994 International Congress of Comparative Law, Athens, 1994 (Cowansville, Que: Yvon Blais, 1995) 701 at 701. Howse warns that it was deployed in this manner at the end of the $19^{\text {th }}$ century by the Catholic Church in order to defend Church power against democratic and socialist forces. In other words, lower levels of association may not in fact be more democratic and "closer to the people." Ibid at 702.

1182010 SCC 61, 327 DLR (4th 257 at para 69. McLachlin CJ's reasons are supported by Binnie, Fish and Charron JJ.

119 S 91(24) of the Constitution Act, 1867 (UK), 30\&31 Vict, c 3, reprinted in RSC 1985, App II, No 5.

120 [1976] 2 SCR 751. 60 DLR (3d) 148.

121 Ryder, supra note 90 at 363.

122 Ibid at $363,379$.
123 See e.g. $R v$ Morgentaler, [1993] 3 SCR 463, 107 DLR (4th) 537

124 See supra note 117 regarding the anti-democratic history of the principle of subsidiarity.

125 Young, Inclusion and Democracy, supra note 102 at 68 .

126 See, in addition to Ryder's argument, Jean Leclair, "Federal Constitutionalism and Aboriginal Difference” (2006) 31 Queen's LJ 521; and John Borrows, Canada's Indigenous Constitution (Toronto: University of Toronto Press, 2010) at 198-201.

127 Young, “Activist Challenges," supra note 102 at 684. 